\title{
Lactobacillus frumenti sp. nov., a new lactic acid bacterium isolated from rye-bran fermentations with a long fermentation period
}

\author{
Martin R. A. Müller, Matthias A. Ehrmann and Rudi F. Vogel
}

Author for correspondence: Matthias A. Ehrmann. Tel: +49 8161 713301. Fax: +498161 713327. e-mail:m.ehrmann@bl.tum.de

Lehrstuhl für Technische Mikrobiologie, Technische Universität München, Weihenstephaner Steig 16, 85350 Freising, Germany

\begin{abstract}
Within the framework of the characterization of the microflora of an industrial sourdough fermentation, strains of Lactobacillus amylovorus, Lactobacillus pontis and two other strains were isolated which could not be associated with a valid species. These latter strains were Gram-positive, catalase-negative, nonspore-forming, non-motile rods that could be clearly differentiated from known species by 165 rDNA sequence analysis. For further characterization, the morphological, physiological (sugar fermentation, formation of DL-lactate, hydrolysis of arginine, growth temperature, $\mathrm{CO}_{2}$ production) and chemotaxonomic ( $G+C$ content, cell wall composition, SDS-PAGE of whole-cell proteins) properties were determined. Fitting of the complete 16S rDNA sequence into alignments of such sequences, together with the subsequent phylogenetic calculations, allowed the reconstruction of a phylogenetic tree. These data showed that the two strains were phylogenetically related but formed an independent cluster distinct from their closest neighbours, L. pontis, Lactobacillus panis, Lactobacillus oris, Lactobacillus vaginalis and Lactobacillus reuteri. The results of DNA-DNA hybridization experiments indicated that the two isolates represent a new Lactobacillus species, for which the name Lactobacillus frumenti is proposed; the type strain of this species is DSM $13145^{\top}$ ( = LMG 19473').
\end{abstract}

Keywords: Lactobacillus frumenti, new species, sourdough, type II, fermentation

\section{INTRODUCTION}

Lactic acid bacteria (LAB), especially the genera Lactococcus, Leuconostoc, Pediococcus and Lactobacillus, play an important role in fermentative food and feed production (Herrero et al., 1996). In nonlactic fermentations, lactobacilli, in particular, contribute to a huge variety of spontaneously fermented indigenous foods and beverages as well as to biotechnological processes carried out under controlled conditions.

The fermentation of starchy substrates can be found in many countries. Numerous reports have elucidated the microbial populations involved in such fermentations, e.g. fermentation of sour cassava (Figueroa et al.,

Abbreviations: chrDNA, chromosomal DNA; LAB, lactic acid bacteria; RAPD, randomly amplified polymorphic DNA.

The EMBL accession number for the 16S rDNA sequence of Lactobacillus frumenti strain DSM $13145^{\top}$ is AJ250074.
1995; Giraud et al., 1998; Morlon-Guyot et al., 1998), ogi (Johansson et al., 1995), pozol (Ampe et al., 1998) and kishra (Hamad et al., 1997). In Europe, cereal fermentations are mainly applied to the brewing industry, providing sourmashes, and to baking, in which sourdough plays an important role in the preparation of bread dough to improve dough machinability, breadcrumb structure, keeping properties and flavour (Salovaara, 1998). The microbial ecology of such cereal fermentations is determined by several exogenous and endogenous parameters, as reported by Vogel et al. (1996). Whilst a wide variety of LAB, e.g. Lactobacillus brevis, Lactobacillus alimentarius, Lactobacillus farciminis, Weissella confusa or Enterococcus faecium, can be found in spontaneous homemade sourdough fermentations, Lactobacillus sanfranciscensis, Lactobacillus pontis and Lactobacillus panis are endemic in cereal fermentations, because their competitive metabolism has adapted to this environment. Böcker et al. (1995) introduced a classification of industrial sourdough fermentations which 
takes the kind of propagation and the manner of preparation into consideration, resulting in typical bacterial communities. Whilst $L$. sanfranciscensis constitutes a stable element (Böcker et al., 1990) in the socalled type I doughs, micro-organisms found in liquid doughs with an extended fermentation period and higher temperatures (type II) belong to the species L. pontis, L. panis, Lactobacillus reuteri, Lactobacillus fermentum and Lactobacillus amylovorus (Vogel et al., 1999).

In this paper we report the description of a new Lactobacillus species from an industrial type II ryebran fermentation and for which we propose the name Lactobacillus frumenti.

\section{METHODS}

Strains, medium and culture conditions. Strains were isolated from an industrial rye-bran sourdough fermentation. For cultivation, the modified MRS medium (mMRS) described by Vogel et al. (1994) was prepared with an additional modification whereby $90 \%$ of the water was replaced with a rye-bran extract. For the preparation of 11 of this extract, $40 \mathrm{~g}$ rye bran and $2 \mathrm{~g}$ malted wheat meal together with $0.8 \mathrm{~g}$ trypsin were incubated for $24 \mathrm{~h}$ at $50{ }^{\circ} \mathrm{C}$. The liquid was separated by filtration. Strains of $L$. frumenti were incubated at $40^{\circ} \mathrm{C}$ in line with the fermentation temperature of the sourdough from which they were isolated. The other strains were incubated at the temperature recommended by the respective strain collection. Solid media were incubated under a modified atmosphere $\left(\mathrm{N}_{2}: \mathrm{CO}_{2} 90 \%: 10 \%, \mathrm{v} / \mathrm{v}\right)$. Cultures were maintained at $-80{ }^{\circ} \mathrm{C}$ in glycerol (a pellet of $10 \mathrm{ml}$ overnight culture in $500 \mu \mathrm{l}$ fresh medium to $500 \mu \mathrm{l}$ glycerol). The purity of the cultures was checked microscopically and by preparing streak cultures. The two isolates that are described here as the new species $L$. frumenti $\mathrm{sp}$. nov. bear the numbers of the strain collection of the Technische Mikrobiologie Weihenstephan, i.e. TMW 1.655 and TMW 1.666. Strain TMW 1.666 was deposited as the type strain of the species as LMG $19473^{\mathrm{T}}$ and DSM $13145^{\mathrm{T}}$, and will be referred to as the latter in this paper. The following type strains were used as reference organisms: Lactobacillus vaginalis DSM $5837^{\mathrm{T}}$, L. pontis DSM $8475^{\mathrm{T}}$, L. panis DSM $6035^{\mathrm{T}}$, L. reuteri DSM 20016 ${ }^{\mathrm{T}}$, Lactobacillus oris DSM $4864^{\mathrm{T}}$, Lactobacillus buchneri DSM $20057^{\mathrm{T}}$.

Physiological characterization. Sugar-fermentation patterns were determined by using a microtitre plate assay. The reproducibility was verified by repeated analysis using cultures grown on mMRS. All sugar solutions $(2 \% \mathrm{w} / \mathrm{w})$ were sterilized by filtration through a $0.2 \mu \mathrm{m}$ filter. Cells were suspended in a medium containing (per $250 \mathrm{ml}) 5 \mathrm{~g}$ peptone from casein, $1 \mathrm{~g}$ meat extract, $3.5 \mathrm{~g}$ yeast extract, $125 \mathrm{mg}$ cysteine, $250 \mu \mathrm{l}$ Tween $80,100 \mathrm{mg}$ bromecresol purple, $2.5 \mathrm{~g}$ sodium acetate, $250 \mathrm{mg}$ citric acid (ammonium salt), $62.5 \mathrm{mg} \mathrm{KH} \mathrm{PO}_{4}, 125 \mathrm{mg} \mathrm{Na}{ }_{2} \mathrm{HPO}_{4}, 100 \mathrm{mg} \mathrm{MgSO}_{4}$, $5 \mathrm{mg} \mathrm{MnSO}_{4}$ and $5 \mathrm{mg} \mathrm{FeSO}_{4}$. The solution was autoclaved for $15 \mathrm{~min}$ at $121^{\circ} \mathrm{C}$. A $2 \mathrm{ml}$ aliquot of an overnight culture of each strain was centrifuged and washed three times with $2 \mathrm{ml}$ PBS buffer ( $8 \mathrm{~g} \mathrm{NaCl}, 0.2 \mathrm{~g} \mathrm{KCl}, 1.44 \mathrm{~g} \mathrm{Na}_{2} \mathrm{HPO}_{4}$, $0.24 \mathrm{~g} \mathrm{KH}_{2} \mathrm{PO}_{4}$ made to 11 with $\mathrm{dH}_{2} \mathrm{O}, \mathrm{pH} 7 \cdot 4$ ). The cell concentration was adjusted with water to an $\mathrm{OD}_{578}$ of 1 ; $45 \mu \mathrm{l}$ of this cell suspension was added to $1155 \mu \mathrm{l}$ test medium. From this cell suspension, aliquots of $40 \mu \mathrm{l}$ were added to each of the wells. In the first well, sugar was replaced with sterile water. To avoid evaporation and to guarantee anaerobic conditions, the wells were covered with paraffin. The change of the indicator from purple to yellow was documented after 24, 48 and $168 \mathrm{~h}$. Only definitive changes were rated as positive results. To evaluate the system, additional experiments were carried out using the API $50 \mathrm{CH}$ kit (bioMérieux).

The formation of the lactate isomeres in the fermented broth was determined enzymically using the DL-lactate test kit (Boehringer Mannheim).

Arginine hydrolysis was determined according the methods described by Sharpe (1979).

Morphological characteristics. Cell morphology was studied using phase-contrast microscopy. Gram-determinations were performed using the KOH method of Gregersen (1978).

Whole-cell protein analysis. For the preparation of cell extracts, 70-80 mg (wet weight) of bacterial cells was treated as described by Vogel et al. (1994). Electrophoresis was performed as described by Laemmli (1970), using a $12 \%$ (v/v) SDS-polyacrylamide separating gel. Gels were run in a Mini-Protean II electrophoresis cell (Bio-Rad), Coomassiestained and dried on a vacuum gel dryer. The protein patterns were compared visually. The LMW electrophoresis calibration kit (Amersham Pharmacia Biotech) was used as a size marker.

DNA base composition. The $\mathrm{G}+\mathrm{C}$ contents $(\mathrm{mol} \%)$ of the DNA of strains TMW 1.655 and DSM 13145 determined using an HPLC analytical method. The experiments were performed by the DSMZ and were carried out using the protocol previously described by Tamaoka \& Komagata (1984). Wild-type lambda phage DNA was used as the standard (Mesbah et al., 1989). The $\mathrm{G}+\mathrm{C}$ content (mol\%) was determined according to Mesbah et al. (1989).

Cell wall. The peptidoglycan structure of the cell wall was determined by the DSMZ.

DNA isolation. DNA was isolated according a protocol described by Marmur (1961), with some modifications. One hour before cells were harvested, penicillin G (Sigma) was added to inhibit the synthesis of cross-linkages of the cell wall and therefore to facilitate the lysis. A wet weight of $70 \mathrm{mg}$ cells was used for the DNA isolation. After the protocol, lysis was completed within 45-90 min after the addition of lysozyme and mutanolysine. For some strains, more effective lysis was obtained by using an overnight lysis at $4{ }^{\circ} \mathrm{C}$ and a subsequent proteinase $\mathrm{K}$ treatment at $60^{\circ} \mathrm{C}$ for $1 \mathrm{~h}$, before continuation with the normal protocol. The purified and vacuum-dried DNA was dissolved in $2 \times$ SSC $\left(0.3 \mathrm{M} \mathrm{NaCl}, 0.03 \mathrm{M} \mathrm{Na}_{3}\right.$ citrate. $\left.2 \mathrm{H}_{2} \mathrm{O}, \mathrm{pH} 7 \cdot 0\right)$. This DNA preparation served for the DNA-DNA hybridization experiments as well as for $16 \mathrm{~S}$ rDNA amplification. The purity of the culture subjected to DNA isolation was proved as described above before the addition of penicillin. Furthermore, DNA preparations were checked for their authenticity in a randomly amplified polymorphic DNA (RAPD)-PCR assay (Paramithiotis et al., 2000), comparing the patterns with those of primary preparations.

DNA-DNA hybridization. The determination of DNA homology values was carried out by using chromosomal DNA (chrDNA) from strain DSM $13145^{\mathrm{T}}$ and from L. pontis DSM $8475^{\mathrm{T}}$ as probes. These chrDNA probes were labelled by nick translation using a kit system (Promega) incorporating biotin-21-dUTP (Clontech) for $2 \mathrm{~h}$ at $16^{\circ} \mathrm{C}$. The DNA $(5 \mu \mathrm{g})$ of selected type strains was transferred by using a dot-blot block (Stratagene) on a positively charged nylon membrane (Boehringer Mannheim) and then fixed by incubation at $80^{\circ} \mathrm{C}$ for $1 \mathrm{~h}$. The DNA of L. buchneri DSM 
Table 1. Physiological and biochemical characteristics of $L$. frumenti and selected reference organisms

-, Negative reaction; + , positive reaction; ND, not determined. All strains contain DL-lactate, produce $\mathrm{CO}_{2}$ from glucose, and produce acid from glucose, maltose and sucrose.

\begin{tabular}{|c|c|c|c|c|c|c|c|}
\hline Characteristic & $\begin{array}{c}\text { L. frumenti } \\
\text { DSM } 13145^{\mathrm{T}}\end{array}$ & $\begin{array}{l}\text { L. frumenti } \\
\text { TMW } 1.655\end{array}$ & $\begin{array}{c}\text { L. panis } \\
\text { DSM 6035 }\end{array}$ & $\begin{array}{c}\text { L. pontis } \\
\text { DSM 8475 }\end{array}$ & $\begin{array}{l}\text { L. vaginalis } \\
\text { DSM } 5837^{7}\end{array}$ & $\begin{array}{c}\text { L. oris } \\
\text { DSM 4864 }{ }^{\mathrm{T}} \S\end{array}$ & $\begin{array}{c}\text { L. reuteri } \\
\text { DSM 20016 }\end{array}$ \\
\hline $\mathrm{NH}_{3}$ from arginine & + & + & - & + & + & - & + \\
\hline Growth at $15^{\circ} \mathrm{C} / 45^{\circ} \mathrm{C}$ & $+1-$ & $+1-$ & $+/-$ & $+/+$ & $+1-$ & $+/-$ & $+1-$ \\
\hline Peptidoglycan type & L-Lys-D-Asp & L-Lys-D-Asp & L-Lys-D-Asp & Orn-D-Asp & Orn-D-Asp & L-Lys-D-Asp & L-Lys-D-Asp \\
\hline DNA G $+\mathrm{C}$ content $(\mathrm{mol} \%)$ & $43 \cdot 3 \pm 0 \cdot 2$ & $44 \cdot 4 \pm 0 \cdot 3$ & $48 \cdot 3 \pm 0 \cdot 3$ & $53-569$ & $38-41 * *$ & $49-51^{* *}$ & $40-42^{* *}$ \\
\hline \multicolumn{8}{|l|}{ Acid production from: } \\
\hline DL-Arabinose & $+/-$ & $-/-$ & $+1-$ & $-/-$ & - & $+1-$ & $\mathrm{ND} /+$ \\
\hline Ribose & + & + & + & + & - & + & + \\
\hline DL-Xylose & - & - & + & - & - & $+1-$ & $-/ \mathrm{ND}$ \\
\hline Galactose & + & + & + & - & + & + & + \\
\hline Fructose & + & + & + & + & ND & + & + \\
\hline Mannose & + & + & + & - & ND & + & - \\
\hline Mannitol & + & + & - & - & - & - & - \\
\hline Sorbitol & + & + & ND & - & - & - & - \\
\hline$N$-Acetylglucosamine & + & + & - & - & - & - & - \\
\hline Amygdalin & + & + & - & - & ND & + & - \\
\hline Arbutin & + & + & - & - & - & + & - \\
\hline Aesculin & + & + & + & - & - & - & - \\
\hline Salicin & + & + & + & - & - & - & - \\
\hline Cellobiose & + & + & - & - & - & + & - \\
\hline Lactose & + & + & + & - & + & + & + \\
\hline Melibiose & + & + & + & - & + & + & + \\
\hline Trehalose & + & + & - & - & - & + & - \\
\hline Melezitose & + & - & - & - & - & - & - \\
\hline Raffinose & + & + & + & - & + & + & + \\
\hline Gluconate & + & + & - & - & - & + & + \\
\hline
\end{tabular}

* Data are from Wiese et al. (1996).

$\dagger$ Data are from Vogel et al. (1994); acid production from sugars was tested in this study.

† Data are from Embley et al. (1989).

$\S$ Data are from Farrow \& Collins (1988).

\| Data are from Kandler et al. (1980) and Axelsson \& Lindgren (1987).

- Determined by the HPLC method.

** Determined by the thermal denaturation method.

$20054^{\mathrm{T}}$ was included to check the sensitivity of the system for a more distantly related Lactobacillus species. The hybridization procedure was carried out as described by Ehrmann et al. (1994), except for the hybridization and washing steps, which were performed with alternative buffers described in the protocol of Engler-Blum et al. (1993). To determine the accessibility of the DNA, a parallel hybridization was carried out with a $5^{\prime}$ biotin-labelled universal probe $\left(612 \mathrm{R}, 5^{\prime}-\right.$ GTAAGGTTYTNCGCGT-3') targeting the 16S rDNA. For the hybridization, $100 \mathrm{ng}$ chrDNA probe and $20 \mathrm{pmol}$ oligo probe (each per $\mathrm{ml}$ hybridization solution) were used. Hybridization was performed at $65^{\circ} \mathrm{C}$ for the chrDNA probe and at $42{ }^{\circ} \mathrm{C}$ for the oligo probe. The detection system consisted of a combination of alkaline phosphatase and the substrate CDP-Star (Boehringer Mannheim). Membranes were exposed to a Kodak X-Omat film (Sigma-Aldrich). The spot intensity was calculated with IMAGE MASTER 2D Elite software (Amersham Pharmacia Biotech). Calculations of homology values were performed in principle as described by Liebl et al. (1991).

Additional DNA-DNA hybridization experiments for $L$. frumenti DSM 13145 , L. frumenti TMW 1.655 and $L$. vaginalis DSM $5837^{\mathrm{T}}$ were performed by the DSMZ according to the protocol of De Ley et al. (1970), but with the modifications described by Huß et al. (1983) and Escara \& Hutton (1980). The renatuartion rates were calculated according to Jahnke (1992) with the program TRANSFER: BAS.
$16 \mathrm{~S}$ rDNA amplification and sequencing. PCR-mediated amplification of the complete $16 \mathrm{~S}$ rDNA was carried out in a Gradient Master thermocycler (Eppendorf). All reagents were from Amersham Pharmacia Biotech, unless otherwise indicated. The amplification conditions were as follows : $1 \mu 1$ genomic DNA, $10 \mu 110 \times$ reaction buffer, $200 \mathrm{nM}$ each of the four deoxynucleotides, $1.5 \mathrm{U}$ Taq polymerase, $20 \mathrm{pmol}$ each primer (Interactiva) (616V, 5'-AGAGTTTGATYMTGGCTCAG-3'; 630R, 5'-CAKAAAGGAGGTGATCC$\left.3^{\prime}\right)$ and $\mathrm{dH}_{2} \mathrm{O}$ to a final volume of $100 \mu \mathrm{l}$. The amplification conditions were as follows: $94{ }^{\circ} \mathrm{C}$ for $2 \mathrm{~min}$; 30 cycles of $94{ }^{\circ} \mathrm{C}$ for $45 \mathrm{~s}, 52{ }^{\circ} \mathrm{C}$ for $1 \mathrm{~min}, 72^{\circ} \mathrm{C}$ for $30 \mathrm{~s} ; 94^{\circ} \mathrm{C}$ for $1 \mathrm{~min}, 72^{\circ} \mathrm{C}$ for $4 \mathrm{~min}$. PCR products were purified by the QIAquick PCR purification kit (Qiagen) and were eluted with $60 \mu$ elution buffer. DNA sequences were determined by the chain-termination method (Sanger et al., 1977) using the Thermo Sequenase fluorescence-labelled primer cycle sequencing kit with 7-deaza-dGTP (Amersham Life Sciences) and separated on an ALF express sequencer (Amersham Pharmacia Biotech) or, alternatively, using the ABI Prism Dye Terminator Cycle Sequencing Kit (Perkin Elmer) on an ABI 373 stretch sequencing system by a commercial service (SequiServe, Germany). For sequencing, the amplification primer $616 \mathrm{~V}$ together with the internal primers 609R [5'-ACT AC(CT) (AGC)GG GTA TCT AA(GT) CC-3'], 612R [5'-GTA AGG TT(CT) T(AGCT)C GCG T-3'], 607R [5'-ACG TGT GTA GCC C-3'], 606R [5'- 
T(AG)A CGG (GC)C(AG) GTG TGT ACA-3'] and 607V [5'-GGG CTA CAC ACG TGC-3'] were used.

Phylogenetic analysis. The complete $16 \mathrm{~S}$ rDNA sequences of L. frumenti DSM $13145^{\mathrm{T}}$ and TMW 1.655 were fitted into alignments of approximately 16000 homologous full and partial primary structures available in public databases (Ludwig, 1995). Distance-matrix, maximum-parsimony and maximum-likelihood methods were applied for tree reconstructions as implemented in the ARB software package (W. Ludwig \& O. Strunk; http://www.mikro.biologie.tumuenchen.de/pub/ARB/documentation/). Different datasets varying with respect to included outgroup reference sequences as well as alignment positions were analysed.

\section{RESULTS}

\section{Colony and cell morphology}

On mMRS, the colonies of L. frumenti DSM $13145^{\mathrm{T}}$ were white with regular sharp edges and, after $3 \mathrm{~d}$ growth, they were $1 \mathrm{~mm}$ in diameter. The colonies of TMW 1.655 were of a similar shape but were a little smaller and appeared whitish and transparent.

The cells of strains TMW 1.655 and $L$. frumenti DSM $13145^{\mathrm{T}}$ were non-spore-forming, non-motile rods that occurred singly or in pairs (seldom in chains). In liquid cultures of mMRS after $24 \mathrm{~h}$ at $40{ }^{\circ} \mathrm{C}$, cells of TMW 1.655 had a tendency to form nest-shaped aggregations. Depending on the period of growth, the ends of the cells were bent like hooks. The cells of $L$. frumenti DSM $13145^{\mathrm{T}}$ were more regular in shape than those of TMW 1.655. The size of a single cell was difficult to determine, because of the heterogeneity. The cell length was between 3 and $5 \mu \mathrm{m}$ and the diameter was $0.3 \mu \mathrm{m}$. The $\mathrm{KOH}$ test indicated Grampositive behaviour.

\section{Physiological and biochemical properties}

The sugar patterns and further physiological and biochemical characteristics of L. frumenti strains and the reference organisms are listed in Table 1. Melezitose, rhamnose, methyl $\alpha$-D-mannoside and Larabinose were fermented only by strain $L$. frumenti DSM $13145^{\mathrm{T}}$. 5-Ketogluconate was fermented only by strain TMW 1.655.

\section{SDS-PAGE pattern}

Both strains of L. frumenti were included in a comparison of the SDS-PAGE pattern of the whole-cell proteins together with those of the type strains of the closest phylogenetic neighbours (Fig. 1). The protein patterns of L. frumenti DSM $13145^{\mathrm{T}}$ and TMW 1.655 were very similar to each other and they could be clearly discriminated from the others.

\section{Phylogenetic position}

For both strain TMW 1.655 and L. frumenti DSM $13145^{\mathrm{T}}, 1561 \mathrm{bp}$ of the $16 \mathrm{~S}$ rDNA were sequenced. Fig. 2 shows a phylogenetic tree based on these sequence data and reflects the phylogenetic position of

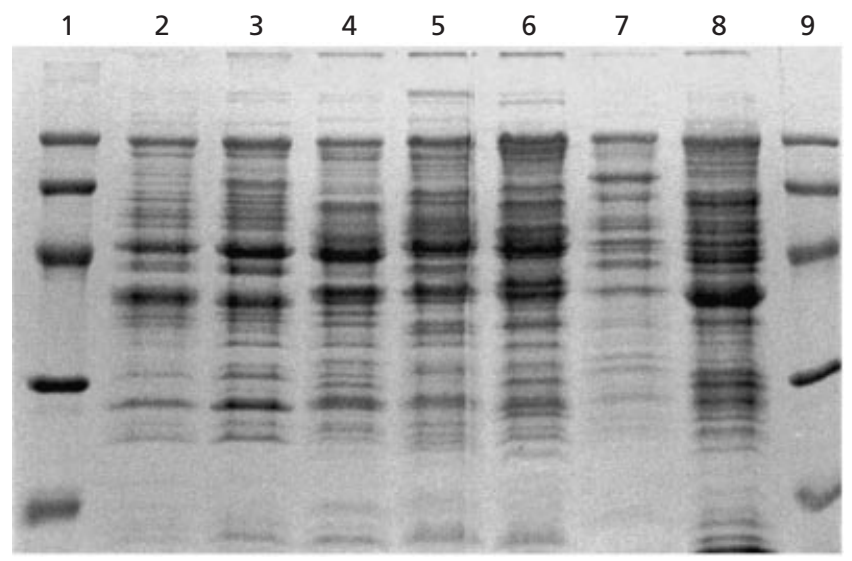

Fig. 1. SDS-PAGE protein patterns. Lanes: $2, L$. frumenti $\mathrm{sp}$. strain DSM $13145^{\top}$; 3, strain TMW 1.655; 4, L. pontis DSM $8475^{\top} ; 5$, L. panis DSM $6035^{\top} ; 6$, L. reuteri DSM $20016^{\top} ; 7$, L. oris DSM 4864 ${ }^{\top}$; and $8, L$. vaginalis DSM $5837^{\top}$. Lanes 1 and 9: molecular mass standards $(94,67,43,30,20 \mathrm{kDa})$.

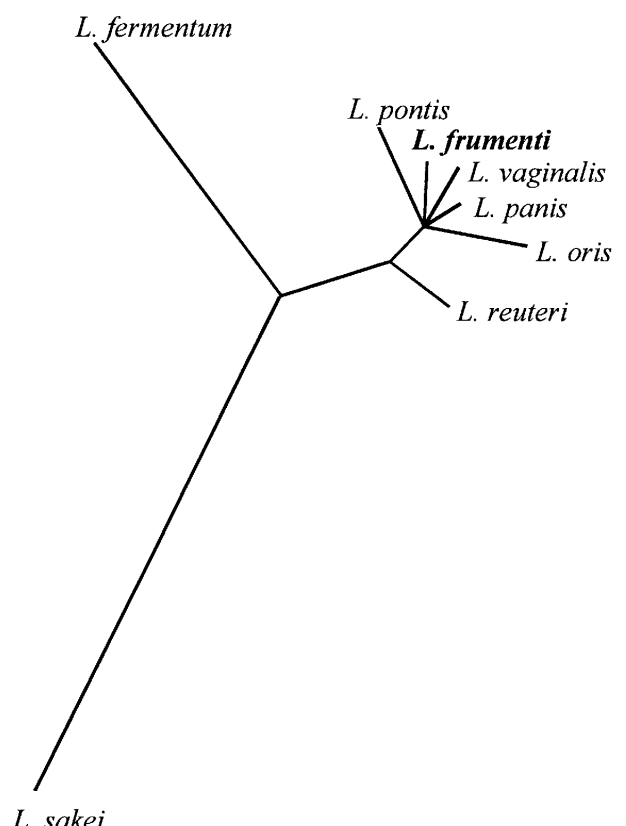

0.10

Fig. 2. Phylogenetic tree demonstrating the relationship between $L$. frumenti DSM $13145^{\top}$ and the most closely related lactobacilli. The tree was constructed by using a maximumlikelihood approach and was based on a dataset that included only those positions present in at least $50 \%$ of all available Lactobacillus 16S rRNA sequences. Bar, 10\% homology divergence.

L. frumenti. The percentage similarities between $L$. frumenti and the type strains of the other species were as follows: L. vaginalis, $97.7 \%$; L. panis, $97.6 \% ; L$. pontis, $97.3 \%$; L. oris, $96.8 \%$; L. reuteri, $94.3 \%$. The 16S rRNA sequence of Lactobacillus sakei was used as an outgroup rRNA reference. 
Table 2. Percentage DNA-DNA hybridization results

\begin{tabular}{|lccc|}
\hline Strain & $\begin{array}{c}\text { L. frumenti } \\
\text { DSM 13145 }\end{array}$ & $\begin{array}{c}\text { L. pontis } \\
\text { DSM 8475 }^{\text {T }}\end{array}$ & $\begin{array}{c}\text { L. vaginalis } \\
\text { DSM 5837 }^{\text {T }}\end{array}$ \\
\hline L. pontis DSM 8475 & 48 & 100 & ND \\
L. panis DSM 6035 & 49 & 43 & ND \\
L. oris DSM 4864 & 66 & 29 & ND \\
L. vaginalis DSM 5837 & 74 & 21 & ND \\
L. reuteri DSM 20016 & 49 & 20 & ND \\
L. buchneri DSM 20057 & 27 & 12 & ND \\
L. frumenti DSM 13145 & 100 & 46 & $41^{\text {T }}$ \\
L. frumenti TMW 1.655 & 90 & 33 & $45^{*}$ \\
\hline
\end{tabular}

* Data were obtained by the spectrophotometric method.

\section{DNA homology}

The DNA-DNA hybridization studies were performed with chrDNA from L. frumenti DSM $13145^{\mathrm{T}}$ against the DNA of the relevant type strains exhibiting a strong phylogenetic relationship to L. frumenti. To evaluate the hybridization system for the calculation of DNA-DNA homology values, DNA from L. pontis DSM $8475^{\mathrm{T}}$ served as a probe against the same strains. Because of the high homology values between the $L$. frumenti strains and L. vaginalis, both strains were included in an additional spectrophotometrical DNA-DNA hybridization experiment against the latter to verify their independent position as a new species (Table 2).

\section{DISCUSSION}

Reliable identification techniques are fundamental to the unequivocal description of natural fermentation communities. Although methods that target the phenotypes of bacteria lead to an understanding of the physiological properties, for an increasing number of species, identification remains ambiguous. The $16 \mathrm{~S}$ rDNA molecule emerged as the main target for identification purposes, reflecting the natural relationships of prokaryotes, and has improved our knowledge of the generic and suprageneric relationships among LAB. Within the framework of microbial investigations of long-term rye-bran fermentations, we isolated Lactobacillus strains which were identified by comparative $16 \mathrm{~S}$ rDNA sequence analysis. They were phylogenetically most closely related to L. vaginalis, but formed an independent cluster.

On the basis of comparative sequence analysis and phylogenetic calculations, Schleifer \& Ludwig (1995) proposed a species-specific grouping of LAB. Thus, $L$. frumenti strains clustered in the L. reuteri subgroup of the Lactobacillus case - Pediococcus group, comprising only obligate heterofermentative lactobacilli, namely L. oris, L. panis, L. pontis, L. vaginalis, L. reuteri and L. fermentum. Starting from these $16 \mathrm{~S}$ rDNA data and comparative sequence analysis, a determination of

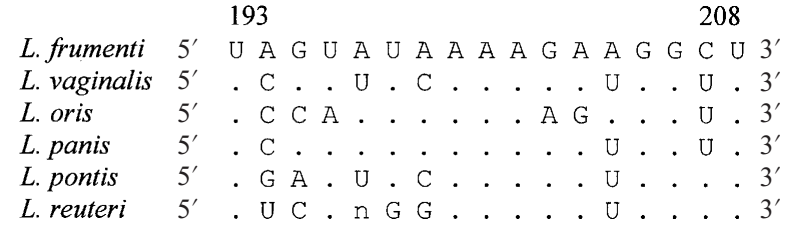

Fig. 3. Diagnostic region 193-208 (Brosius et al., 1981) of the $16 \mathrm{~S}$ rRNA, which shows sufficient sequence variability to differentiate $L$. frumenti from other lactic acid bacteria. Dots indicate sequence identity to the $L$. frumenti sequence.

sufficient sequence variation in the V2 region (Neefs et al., 1990) of the 16S rDNA was feasible, which offered the possibility of distinguishing L. frumenti from other even closely related species (Fig. 3). A PCR-based system that allows $L$. frumenti to be differentiated from these and other sourdough lactobacilli has already been described by Müller et al. (2000). This supports the hypothesis that strains DSM $13145^{\mathrm{T}}$ and TMW 1655 should be separated from other members of the L. reuteri group.

Despite the close phylogenetic relationships of species within the $L$. reuteri group, $\mathrm{G}+\mathrm{C}$ DNA contents range between 38 and $54 \mathrm{~mol} \%$. The closest phylogenetic neighbour of $L$. frumenti (with a $16 \mathrm{~S}$ rDNA similarity of $97 \cdot 7 \%$ ) is L. vaginalis. This relationship is confirmed by their similar $\mathrm{G}+\mathrm{C}$ content (43.3 versus $41 \mathrm{~mol} \%$ ). The biggest difference in the $\mathrm{G}+\mathrm{C}$ contents was shown with L. pontis. In this case, no correlation with $16 \mathrm{~S}$ rRNA homology data can be deduced.

The relatedness of $L$. frumenti and $L$. vaginalis with respect to $\mathrm{G}+\mathrm{C}$ content and $16 \mathrm{~S}$ rRNA sequence data contrasts with the chemical composition of the cell walls of these micro-organisms. L. frumenti has a cell wall of the peptidoglycan type [A $4 \alpha$ (L-Lys-D-Asp)], which constitutes the main feature of species of the $\mathrm{Cb}$ group (Hammes \& Vogel, 1995). The cell wall of $L$. vaginalis is in the same group but lysine is replaced by ornithine, which can be seen as additional proof of the status of as L. frumenti as an independent species. 
SDS-PAGE pattern analysis of whole-cell proteins has proven to be a reliable tool for the discrimination of even closely related species (Pot et al., 1993). SDSPAGE comparisons (in which the two strains of $L$. frumenti exhibited almost identical patterns) allowed L. frumenti DSM $13145^{\mathrm{T}}$ and TMW 1.655 to be clearly differentiated from the species $L$. pontis, L. panis, $L$. oris, $L$. vaginalis and $L$. reuteri. This, again, can be seen as a further proof of the independent status of $L$. frumenti as a new species.

The determination of DNA reassociation values constitutes a meaningful method for unequivocal species description (Stackebrandt \& Goebel, 1994). In particular, when closely related species $(\geqslant 97 \%$ rRNA homology) are inspected, the resolution power of $16 \mathrm{~S}$ rRNA sequences is limited (Fox et al., 1992), but DNA similarity can range between 10 and $100 \%$ (Stackebrandt \& Goebel, 1994). The threshold value for the phylogenetic definition of a species, as proposed by Wayne et al. (1987), should not exceed $70 \%$. In our case, the DNA-DNA hybridization studies clearly adhered to this principle. For $L$. vaginalis and $L$. pontis, rRNA similarity values with respect to $L$. frumenti were 97.7 and $97.3 \%$, respectively. However, DNA-DNA homology values between $L$. frumenti and $L$. vaginalis and between $L$. frumenti and L. pontis amounted to 74 and $48 \%$, respectively. The spectrophotometric technique used as a reference method for the determination of homology values for the closest relative, $L$. vaginalis, produced lower values between L. vaginalis and TMW 1.655 or DSM $13145^{\mathrm{T}}$ (41 and $45 \%$, respectively). The homology values obtained by dot-blot hybridization of $L$. frumenti against the other species were confirmed by alternative hybridization with the DNA of $L$. pontis. The value for similarity to $L$. frumenti $(46 \%)$ was almost identical to that determined by hybridization of $L$. frumenti against $L$. pontis $(48 \%)$. Moreover, the similarity calculated between L. pontis and L. panis was identical $(43 \%)$ to the value determined by the spectrophotometric technique (Wiese et al., 1996). Small differences in the homology values (up to $8 \%$ ) are possible between the strains of one species and other reference organisms (see Wiese et al., 1996). Summarizing the DNA hybridization results (Table 2), all species could be clearly separated from $L$. frumenti, indicating its independent status as a species.

In view of the phylogenetic evidence (16S rDNA, DNA-DNA homology) presented, the protein-pattern differences measured by SDS-PAGE and the phenotypic distinctiveness of DSM $13145^{\mathrm{T}}$ and TMW 1.655, it is proposed that these strains belong to a new species, L. frumenti sp. nov.

\section{Description of Lactobacillus frumenti sp. nov. (Müller, Ehrmann and Vogel)}

Lactobacillus frumenti (fru.men'ti. L. gen. n. frumenti from cereal).
The cells are Gram-positive, non-motile, non-sporeforming rods that occur singly or in pairs (seldom in chains). Growth was observed at temperatures up to $45^{\circ} \mathrm{C}$ but not at $15^{\circ} \mathrm{C}$. They are facultatively anaerobic, catalase-negative and obligately heterofermentative. The L-isomer constitutes more than $85 \%$ of the total lactic acid content. Acid is produced from L-arabinose, ribose, galactose, glucose, fructose, mannose, mannitol, sorbitol, $N$-acetylglucosamine, amygdalin, arbutin, aesculin (hydrolysed), salicin, cellobiose, maltose, lactose, melibiose, sucrose, trehalose, raffinose and gluconate. Melezitose, rhamnose, methyl $\alpha$-D-mannoside and L-arabinose were fermented only by strain DSM $13145^{\mathrm{T}}$. 5-Ketogluconate was fermented only by strain TMW 1.655 . The type strain is Lactobacillus frumenti DSM $13145^{\mathrm{T}}\left(=\mathrm{LMG} 19473^{\mathrm{T}}\right)$.

\section{ACKNOWLEDGEMENTS}

This work was supported by a grant from the European Union (FAIR project CT 96 1126) and by Ernst Böcker $\mathrm{GmbH} \&$ Co. KG (Minden, Germany). We thank Dr Wolfgang Ludwig for the phylogenetic calculations and the reconstrution of the phylogenetic tree. We also wish to thank Jürgen Behr for performing all the physiological experiments.

\section{REFERENCES}

Ampe, F., Ben Omar, N. \& Guyot, J.-P. (1998). Recovery of total microbial RNA from lactic acid fermented foods with a high starch content. Lett Appl Microbiol 27, 270-274.

Axelsson, L. \& Lindgren, S. (1987). Characterization and DNA homology of Lactobacillus strains isolated from pig intestine. J Appl Bacteriol 62, 433-440.

Böcker, G., Vogel, R. F. \& Hammes, W. P. (1990). Lactobacillus sanfrancisco als stabiles Element in einem Reinzucht-SauerteigPräparat. Getreide Mehl Brot 44, 269-274.

Böcker, G., Stolz, P. \& Hammes, W. P. (1995). Neue Erkenntnisse zum Ökosystem Sauerteig und zur Physiologie des sauerteigtypischen Stämme Lactobacuillus sanfrancisco und Lactobacillus pontis. Getreide Mehl Brot 49, 370-374.

Brosius, J., Dull, T. J., Sleeter, D. D. \& Noller, H. F. (1981). Gene organisation and primary structure of a ribosomal RNA operon from Escherichia coli. J Mol Biol 148, 107-127.

De Ley, J., Cattoir, H. \& Reynaerts, A. (1970). The quantitative measurement of DNA hybridization from renaturation rates. Eur J Biochem 12, 133-142.

Ehrmann, M., Ludwig, W. \& Schleifer, K. H. (1994). Reverse dot blot hybridization: a useful method for the direct identification of lactic acid bacteria in fermented food. FEMS Microbiol Lett 117, 143-150.

Embley, T. M., Faquir, N., Bossart, W. \& Collins, M. D. (1989). Lactobacillus vaginalis $\mathrm{sp}$. nov. from the human vagina. Int $J$ Syst Bacteriol 39, 368-370.

Engler-Blum, G., Meier, M., Frank, J. \& Müller, G. A. (1993). Reduction of background problems in non-radioactive northern and southern blot analysis enables higher sensitivity than ${ }^{32}$ P-based hybridization. Anal Biochem 210, 235-244.

Escara, J. F. \& Hutton, J. R. (1980). Thermal stability and renaturation of DNA in dimethyl-sulphoxide solutions: acceleration of renaturation rate. Biopolymers 19, 1315-1327. 
Farrow, J. A. E. \& Collins, M. D. (1988). Lactobacillus oris sp. nov. from the human oral cavity. Int J Syst Bacteriol 38, 116-118.

Figueroa, C., Davilla, A. M. \& Pourquié, J. (1995). Lactic acid bacteria of the sour cassava starch fermentation. Lett Appl Microbiol 21, 126-130.

Fox, G. E., Wisotzkey, J. D. \& Jurtshuk, P., Jr (1992). How close is close: 16S rRNA sequence identity may not be sufficient to guarantee species identity. Int J Syst Bacteriol 42, 166-170.

Giraud, E., Champailler, A., Moulard, S. \& Raimbault, M. (1998). Development of a miniaturized selective counting strategy of lactic acid bacteria for evaluation of mixed starter in a model cassava fermentation. J Appl Microbiol 84, 444-450.

Gregersen, T. (1978). Rapid method for distinction of Gramnegative from Gram-positive bacteria. Eur J Appl Microbiol Biotechnol 5, 123-127.

Hamad, S. H., Dieng, M. C., Ehrmann, M. A. \& Vogel, R. F. (1997). Characterization of the bacterial flora of Sudanese sorghum flour and sorghum sourdough. J Appl Microbiol 83, 764-770.

Hammes, W. P. \& Vogel, R. F. (1995). The genus Lactobacillus. In The Genera of Lactic Acid Bacteria, pp. 19-54. Edited by B. J. B Wood \& W. Holzapfel. Glasgow: Blackie.

Herrero, M., Mayo, B., González, B. \& Suárez, J. E. (1996). Evaluation of technologically important traits in lactic acid bacteria isolated from spontaneous fermentations. $J \mathrm{Appl}$ Bacteriol 81, 565-570.

Huß, V. A. R., Festl, H. \& Schleifer, K. H. (1983). Studies on the spectrophotometric determination of DNA hybridization from renaturation rates. Syst Appl Microbiol 4, 184-192.

Jahnke, K.-D. (1992). BASIC computer program for evaluation of spectroscopic DNA renaturation data from GILFORD SYSTEM 2600 spectrophotometer on a PC/XT/AT type personal computer. J Microbiol Methods 15, 61-73.

Johansson, M.-L., Sanni, A., Lönner, C. \& Molin, G. (1995). Phenotypically based taxonomy using API 50CH of lactobacilli from Nigerian ogi and the occurrence of starch-fermenting strains. Int J Food Microbiol 25, 159-168.

Kandler, O., Stetter, K.-O. \& Köhl, R. (1980). Lactobacillus reuteri sp. nov., a new species of heterofermentative lactobacilli. Zentbl Bakteriol Mikrobiol Hyg Abt 1 Orig C 1, 264-269.

Laemmli, U. K. (1970). Cleavage of structural proteins during the assembly of the head of bacteriophage T4. Nature 227, 680-685.

Liebl, W., Ehrmann, M., Ludwig, W. \& Schleifer, K. H. (1991). Transfer of 'Brevibacterium flavum' DSM 20411, 'Brevibacterium lactofermentum' DSM 20412 and DSM 1412, and Corynebacterium lilium DSM 20137 ${ }^{\mathrm{T}}$ to Corynebacterium glutamicum and their distinction by rRNA gene restriction patterns. Int J Syst Bacteriol 41, 255-260.

Ludwig, W. (1995). Sequence databases. In Molecular Microbial Ecology Manual, pp. 3.3.5.1-22. Edited by A. D. L. Akkermans, J. D. van Elsas \& F. J. de Bruijn. Amsterdam: Kluwer.

Marmur, J. (1961). A procedure for the isolation of deoxyribonucleic acid from microorganisms. J Mol Biol 3, 208-218.

Mesbah, M., Premachandran, U. \& Whitman, W. B. (1989). Precise measurement of the $\mathrm{G}+\mathrm{C}$ content of deoxyribonucleic acid by high-performance liquid chromatography. Int $J$ Syst Bacteriol 39, 159-167.
Morlon-Guyot, J., Guyot, J. P., Pot, B., de Haut, I. J. \& Raimbault, M. (1998). Lactobacillus manihotivorans sp. nov., a new starchhydrolysing lactic acid bacterium isolated during cassava sour starch fermentation. Int J Syst Bacteriol 48, 1101-1109.

Müller, M. R. A., Ehrmann, M. A. \& Vogel, R. F. (2000). Multiplex PCR for the detection of Lactobacillus pontis and two related species in a sourdough fermentation. Appl Environ Microbiol 66, 2113-2116

Neefs, J.-M., van De Peer, Y., De Rijks, P., Chapelle, S. \& De Wachter, R. (1990). Compilation of small ribosomal subunit RNA sequences. Nucleic Acids Res 21, 3025-3049.

Paramithiotis, S., Müller, M. R. A., Ehrmann, M. A., Tsakalidou, E., Seiler, H., Vogel, R. \& Kalantzopoulos, G. (2000). Polyphasic identification of wild yeast strains isolated from Greek sourdoughs. Syst Appl Microbiol 23, 156-164.

Pot, B., Hertel, C., Ludwig, W., Descheemaeker, P., Kersters, K. \& Schleifer, K.-H. (1993). Identification and classification of Lactobacillus acidophilus, L. gasseri and L. johnsonii strains by SDS-PAGE and rRNA-targeted oligonucleotide probe hybridization. J Gen Microbiol 139, 513-517.

Salovaara, H. (1998). Lactic acid bacteria in cereal products. In Lactic Acid Bacteria - Technology and Health Effects, 2nd edn, pp. 115-138. Edited by S. Salminen \& A. Von Wright. New York: Marcel Dekker.

Sanger, F., Nicklen, S. \& Coulson, A. (1977). DNA sequencing with chain-terminating inhibitors. Proc Natl Acad Sci USA 74, 5463-5467.

Schleifer, K. H. \& Ludwig, W. (1995). Phylogeny of genus Lactobacillus and related genera. Syst Appl Microbiol 18, 461-467.

Sharpe, M. E. (1979). Identification of lactic acid bacteria. In Identification Methods for Microbiologists (Technical Series 14), pp. 233-259. Edited by F. A. Skinner \& D. W. Lovelock. London: Academic Press.

Stackebrandt, E. \& Goebel, B. M. (1994). Taxonomic note: a place for DNA-DNA reassociation and 16S rRNA sequence analysis in the present species definition in bacteriology. Int $J$ Syst Bacteriol 44, 846-849.

Tamaoka, J. \& Komagata, K. (1984). Determination of DNA base composition by reversed-phase high-performance liquid chromatography. FEMS Microbiol Lett 25, 125-128.

Vogel, R. F., Böcker, G., Stolz, P. \& 7 other authors (1994). Identification of lactobacilli from sourdough and description of Lactobacillus pontis sp. nov. Int J Syst Bacteriol 44, 223-229.

Vogel, R. F., Müller, M., Stolz, P. \& Ehrmann, M. (1996). Ecology in sourdoughs produced by traditional and modern technologies. Adv Food Sci (CMTL) 18, 152-159.

Vogel, R. F., Knorr, R., Müller, R. A., Steudel, U., Gänzle, M. G. \& Ehrmann, M. A. (1999). Non-dairy lactic fermentations: the cereal world. Antonie Leeuwenhoek 76, 403-411.

Wayne, L. G., Brenner, D. J., Colwell, R. R. \& 9 other authors (1987). International Committee on Systematic Bacteriology. Report of the ad hoc committee on reconciliation of approaches to bacterial systematics. Int J Syst Bacteriol 37, 463-464.

Wiese, B. G., Strohmar, W., Rainey, F. A. \& Diekmann, H. (1996). Lactobacillus panis sp. nov. from sourdough with a long fermentation period. Int $J$ Syst Bacteriol 46, 449-453. 